\title{
Kebijakan Kepemilikan Tunggal Perbankan Di Indonesia Ditinjau Dari Teori Kepentingan Dalam Regulasi Ekonomi
}

\author{
Faishal Rizki Pratama \\ Magister Ilmu Hukum, Universitas Indonesia \\ Email:faisrpratama@gmail.com
}

\begin{abstract}
Abstrak. Konsolidasi perbankan merupakan salah satu prasyarat untuk mewujudkan struktur perbankan Indonesia yang sehat dan kuat guna meningkatkan skala ekonomis dari Bank di Indonesia dan peningkatan efektivitas pengawasan Bank secara terkonsolidasi. Dalam penulisan ini akan dibahas mengenai kebijakan kepemilikan tunggal pada perbankan di Indonesia yang diatur berdasarkan Peraturan Otoritas Jasa Keuangan Nomor 39/POJK.03/2017, yang menitikberatkan pada pembentukan Bank Holding Company (BHC). Penulisan ini menggunakan metode penelitian yuridis normatif yang artinya bahan penelitian yang digunakan adalah data sekunder yang terdiri dari bahanbahan hukum yang mengikat seperti ketentuan peraturan perundang-undangan maupun hasil karya penelitian hukum. Penelitian ini akan menjelaskan bagaimana relevansi antara teori kepentingan dalam regulasi ekonomi sebagaimana dikemukakan oleh Barry M. Mitnick dengan kebijakan kepemilikan tunggal pada perbankan di Indonesia berdasarkan POJK tersebut.
\end{abstract}

Kata Kunci: Kepemilikan Tunggal, Bank Holding Company (BHC), Fungsi Holding.

\begin{abstract}
Banking consolidation is one of the prerequisites for realizing a strong Indonesian banking structure in order to increase the economies of scale of banks in Indonesia and increase the effectiveness of consolidated bank supervision. In this paper, we will discuss the Single Presence policy in banks in Indonesia which is regulated based on the Financial Services Authority Regulation Number 39 / POJK.03 / 2017, which focuses on the formation of a Bank Holding Company (BHC). This writing uses a normative juridical research method, which means that the research material used is secondary data consisting of legally binding materials such as the provisions of laws and regulations as well as the results of legal research work. This study will explain how the relevance of the theory of interest in economic regulation as proposed by Barry M. Mitnick and the Single Presence policy in Indonesian banks based on the POJK.
\end{abstract}

Keywords: Single Presence Policy, Bank Holding Company (BHC), Holding Function.

\section{PENDAHULUAN}

Perbankan adalah segala sesuatu yang menyangkut tentang Bank, mencakup kelembagaan, kegiatan usaha, serta cara dan proses dalam melaksanakan kegiatan usahanya. Dalam menjalankan industri perbankan diperlukan instrumen hukum perbankan. Menurut Muhammad Djumhana, hukum perbankan adalah sebagai kumpulan peraturan hukum yang mengatur kegiatan lembaga keuangan bank yang meliputi segala aspek, dilihat dari segi esensi dan eksistensinya, serta hubungannya dengan bidang kehidupan yang lain.

Konsolidasi perbankan merupakan salah satu prasyarat untuk mewujudkan struktur Jurnal Ilmu Sosial dan Pendidikan perbankan Indonesia yang sehat dan kuat. Diharapkan dengan adanya konsolidasi perbankan terjadi peningkatan skala ekonomis dari Bank di Indonesia dan peningkatan efektivitas pengawasan Bank, khususnya melalui pengawasan Bank secara terkonsolidasi. Sementara itu, rencana integrasi sektor keuangan ASEAN pada tahun 2020 yang memungkinkan Bank dengan kualifikasi tertentu (Qualified ASEAN BanksQAB) bebas beroperasi di kawasan ASEAN, akan meningkatkan persaingan antara Bank nasional dengan bank dari kawasan ASEAN.

Untuk mengantisipasi integrasi sektor keuangan regional dan global tersebut, perlu dilakukan upaya untuk meningkatkan 
ketahanan dan daya saing perbankan nasional, baik melalui akselerasi konsolidasi perbankan maupun upaya-upaya untuk meningkatkan kesehatan Bank, kualitas penerapan tata kelola, maupun meningkatkan permodalan Bank. Perlu disadari bahwa ketahanan dan daya saing perbankan yang kuat sangat dipengaruhi dan membutuhkan dukungan struktur perbankan yang kuat. Struktur perbankan yang kuat menjadi kerangka dasar yang diharapkan mampu mendukung peningkatan perekonomian nasional, antara lain dapat dicapai melalui penataan struktur kepemilikan Bank.

Dengan mempertimbangkan hal di atas dan sehubungan dengan beralihnya fungsi, tugas, dan wewenang pengaturan dan pengawasan jasa keuangan di sektor perbankan dari Bank Indonesia ke Otoritas Jasa Keuangan, terdapat pengaturan kembali terkait Kepemilikan Tunggal pada perbankan Indonesia, yang salah satunya dilakukan dengan memberikan alternatif penyesuaian struktur kepemilikan saham Bank melalui pembentukan Perusahaan Induk di Bidang Perbankan (Bank Holding Company) maupun pelaksanaan Fungsi Holding.

Kebijakan pemilikan tunggal di Indonesia diatur antara lain dalam Peraturan Bank Indonesia Nomor 8/6/PBI/2006 tentang Kepemilikan Tunggal Pada Perbankan Indonesia, yang kemudian dilengkapi dengan Surat Edaran Bank Indonesia Nomor 9/32/DPNP/ tanggal 12 Desember 2007 perihal Kepemilikan Tunggal pada Perbankan Indonesia. Selanjutnya Peraturan Bank Indonesia tersebut berganti dengan Peraturan Bank Indonesia Nomor 14/24/PBI/2012 tentang Kepemilikan Tunggal pada Perbankan Indonesia.

Dalam perkembangannya regulasi atau pengaturan mengenai Kepemilikan Tunggal pada Perbankan mengalami pergeseran berbarengan dengan beralihnya fungsi, tugas, dan wewenang pengaturan dan pengawasan jasa keuangan di sektor perbankan dari Bank Indonesia ke Otoritas Jasa Keuangan. Hal ini dipertegas dengan ketentuan Pasal 18 Peraturan Otoritas Jasa Keuangan (POJK) Nomor 39/POJK.03/2017 Tentang
Kepemilikan Tunggal Pada Perbankan Indonesia yang berbunyi:

"Pada saat Peraturan Otoritas Jasa Keuangan ini mulai berlaku, Peraturan Bank Indonesia Nomor 14/24/PBI/2012 tentang Kepemilikan Tunggal pada Perbankan Indonesia (Lembaran Negara Republik Indonesia Tahun 2012 Nomor 284, Tambahan Lembaran Negara Republik Indonesia Nomor 5382), dicabut dan dinyatakan tidak berlaku."

Merujuk pada bunyi Pasal tersebut, maka dapat diketahui bahwa fungsi regulasi yang dimiliki Bank Indonesia terkait Kepemilikan Tunggal pada Perbankan di Indonesia telah beralih menjadi fungsi yang dikendalikan oleh Otoritas Jasa Keuangan, ditandai dengan lahirnya Peraturan Otoritas Jasa Keuangan (POJK) Nomor 39/POJK.03/2017 Tentang Kepemilikan Tunggal Pada Perbankan Indonesia yang mencabut berlakunya Peraturan Bank Indonesia Nomor 14/24/PBI/2012 tentang Kepemilikan Tunggal pada Perbankan Indonesia.

Penelitian ini akan menganalisis pengaturan tentang Kepemilikan Tunggal (Single Presence Policy) pada Perbankan di Indonesia dalam Tinjauan Politik Hukum dan Teori Kepentingan Dalam Regulasi di Bidang Ekonomi menurut Barry M. Mitnick.

\section{METODE PENELITIAN}

Metode Penelitian yang digunakan dalam penelitian ini merupakan metode penelitian yuridis normatif, yang termasuk dalam lapisan ilmu hukum berupa dogmatika hukum, karena fokus yang dikaji pada penelitian ini adalah aspek penerapan dari hukum positif baik berupa undang-undang maupun dalam bentuk peraturan perundangundangan lainnya sebagai derivatif dari undang-undang itu sendiri. Penelitian hukum normatif atau penelitian kepustakaan dilakukan dengan cara meneliti bahan pustaka atau data sekunder belaka. Penelitian hukum normatif mencakup penelitian terhadap asasasas hukum, sistematika hukum, sinkronisasi hukum, perbandingan hukum dan sejarah hukum. Penelitian ini dilakukan dengan studi kepustakaan terhadap peraturan perundang- 
undangan yang terkait dengan pajak pertambahan nilai dan pertambangan batubara.

Dalam melaksanakan penelitian ini, jenis data yang digunakan ialah data sekunder yang diperoleh melalui studi kepustakaan. Data sekunder merupakan data primer yang telah diolah lebih lanjut dan disajikan baik oleh pihak pengumpul data primer atau oleh pihak lain. Penelitian hukum dalam level dogmatik hukum atau penelitian untuk keperluan praktik hukum ini menggunakan pendekatan perundang-undangan. Dalam penelitian ini, penulis menggunakan beberapa bahan hukum primer yaitu merupakan bahan hukum yang mempunyai kekuatan mengikat antara lain berupa peraturan perundang-undangan.

\section{HASIL DAN PEMBAHASAN}

\section{1) Definisi Bank dan Hukum Perbankan}

Bank adalah badan usaha yang menghimpun dana dari masyarakat dalam bentuk simpanan dan menyalurkan kepada masyarakat dalam bentuk kredit dan atau bentuk-bentuk lainnya dalam rangka meningkatkan taraf hidup rakyat banyak .

Dalam Pasal 5 Undang-Undang Perbankan, menurut fungsinya jenis bank terdiri atas:

a. Bank Umum

Bank Umum adalah bank yang melaksanakan kegiatan usaha secara konvensional dan atau berdasarkan Prinsip Syariah yang dalam kegiatannya memberikan jasa dalam lalu lintas pembayaran.

Bank Umum dapat mengkhususkan diri untuk melaksanakan kegiatan tertentu atau memberikan perhatian yang lebih besar kepada kegiatan tertentu, antara lain:

i. melaksanakan kegiatan pembiayaan jangka panjang;

ii. pembiayaan untuk mengembangkan koperasi;

iii. pengembangan pengusaha golongan ekonomi lemah/ pengusaha kecil;

iv. pengembangan ekspor non migas; dan

v. pengembangan pembangunan perumahan.
Dari pengertian ini, maka dengan sendirinya Bank Umum adalah bank pencipta uang giral.

b. Bank Perkreditan Rakyat

Bank Perkreditan Rakyat (BPR) adalah bank yang melaksanakan kegiatan usaha secara konvensional atau berdasarkan Prinsip Syariah yang dalam kegiatannya tidak memberikan jasa dalam lalu lintas pembayaran.

Dari pengertian ini, maka dengan sendirinya BPR adalah bukan bank pencipta uang giral, sebab BPR tidak ikut memberikan jasa dalam lalu lintas pembayaran.

Menurut bentuk badan usaha, jenis kelembagaan bank dapat dibedakan atas:

a. Bentuk hukum suatu Bank Umum dapat berupa:

1) Perseroan Terbatas;

2) Koperasi;

3) Perusahaan Daerah.

b. Bentuk hukum suatu Bank Perkreditan Rakyat dapat dibedakan atas:

1) Perusahaan Daerah;

2) Koperasi;

3) Perseroan Terbatas; atau

4) Bentuk lain yang ditetapkan dengan Peraturan Pemerintah.

Industri perbankan mempunyai karakteristik usaha yang berbeda apabila dibandingkan dengan industri nonperbankan pada umum-nya. Perbedaan yang mendasar terutama terlihat dari dua aspek, yaitu: pertama, eksistensi lembaga keuangan sangat bergantung pada unsur kepercayaan dan kedua, hubungan bank, masyarakat dan pemerintah merupakan wujud ikatan sosial dalam artian bahwa masyarakat mengharapkan agar pemerintah dapat melindungi hak milik individu.

Menurut Munir Fuady, hukum perbankan merupakan seperangkat kaidah hukum dalam bentuk peraturan perundangundangan, yurisprudensi, doktrin, dan lain-lain sumber hukum, yang mengatur masalahmasalah perbankan sebagai lembaga, dan aspek kegiatannya sehari-hari, rambu-rambu yang harus dipenuhi oleh suatu bank, perilaku petugas-petugasnya, hak, kewajiban, tugas dan 
tanggung jawab para pihak yang tersangkut dengan bisnis perbankan, apa yang boleh dan tidak boleh dilakukan oleh bank, eksistensi perbankan, dan lain-lain yang berkenaan dengan dunia perbankan.

Peraturan perundang-undangan di sektor perbankan serta penegakannya harus dilakukan secara hati-hati dengan memperhatikan akibat ekonominya serta dalam rangka melindungi fungsi perbankan dalam perekonomian negara dan upaya untuk memantapkan kepercayaan masyarakat pada industri perbankan. Nicolas A. Lash mengemukakan ada lima tujuan pengaturan industri perbankan, yaitu:

a. menjaga keamanan agar kegiatan industri perbankan tidak mudah colaps mengingat kegiatan industri perbankan sangat rentan terhadap ketidakpercayaan masyarakat;

b. terciptanya iklim kompetisi yang sehat, bahwa hukum perbankan harus menciptakan suatu kondisi agar tidak terjadi dominasi oleh bank besar terhadap kegiatan industri perbankan secara keseluruhan;

c. memastikan agar bank dapat menyalurkan kredit-kreditnya kepada pihak yang betulbetul memerlukan;

d. melindungi dan menjaga agar nasabah diperlakukan secara adil (fair) oleh bank, berhubung nasabah selalu dalam posisi tawar yang lemah; dan

e. terciptanya suasana yang kondusif bagi pengambilan kebijakan moneter, agar hukum perbankan dapat secara efisien menentukan lembaga-lembaga yang harus mengambil kebijakan moneter.

2) Kepemilikan Tunggal Pada Perbankan Di Indonesia Berdasarkan Peraturan Otoritas Jasa Keuangan Nomor
39/POJK.03/2017

Kepemilikan Tunggal adalah suatu kondisi dimana suatu pihak hanya dapat menjadi pemegang saham pengendali pada 1 (satu) Bank. Pemegang Saham Pengendali yang selanjutnya disingkat PSP adalah badan hukum, orang perseorangan, dan/atau kelompok usaha yang:

a. memiliki saham perusahaan atau Bank sebesar 25\% (dua puluh lima persen) atau lebih dari jumlah saham yang dikeluarkan dan mempunyai hak suara; atau

b. memiliki saham perusahaan atau Bank kurang dari $25 \%$ (dua puluh lima persen) dari jumlah saham yang dikeluarkan dan mempunyai hak suara namun yang bersangkutan dapat dibuktikan telah melakukan pengendalian perusahaan atau Bank, baik secara langsung maupun tidak langsung .

Perusahaan Induk di Bidang Perbankan (Bank Holding Company) yang selanjutnya disingkat BHC adalah badan hukum yang dibentuk dan/atau dimiliki oleh PSP untuk mengonsolidasikan dan mengendalikan secara langsung seluruh aktivitas Bank yang menjadi anak perusahaannya.

BHC dapat berdiri sendiri sebagai 1 (satu) badan hukum atau berupa perusahaan induk di bidang keuangan (financial holding company) yang mengonsolidasikan lembaga keuangan yang dimiliki oleh PSP.

Fungsi Holding adalah suatu fungsi yang dimiliki oleh PSP berupa Bank yang berbadan hukum Indonesia atau instansi Pemerintah Pusat untuk mengonsolidasikan dan mengendalikan secara langsung seluruh aktivitas Bank yang menjadi anak perusahaannya.

Di Indonesia tidak dikenal dengan istilah Universal Banking yang ada adalah Bank yang melakukan kegiatan usaha Commercial Banking dan melakukan kegiatan Investment Banking melalui anak-anak usahanya (grup usaha). Di Amerika Serikat Gramm - Leach Bliley Act (GLBA, 1999) merubah struktur peraturan yang sangat mengatur keuangan industri AS, dengan menghapus aturan yang membatasi afiliasi dan persaingan antara organisasi perbankan, perusahaan keamanan dan perusahaan asuransi, dengan tujuan membina persaingan dan meningkatkan efisiensi produksi perusahaan. Untuk tujuan ini, muncul Financial Holding Company (FHC) yang dapat terlibat dalam berbagai kegiatan keuangan. FHC memiliki sekitar $86 \%$ dari keseluruhan aset konsolidasi semua BHC per Desember 2004. 
Berdasarkan POJK Nomor 39/POJK.03/2017, Otoritas Jasa Keuangan memiliki peran sebagai berikut:

a. melakukan penilaian kemampuan dan kepatutan terhadap calon anggota direksi dan calon anggota dewan komisaris BHC sesuai dengan ketentuan Otoritas Jasa Keuangan yang mengatur mengenai penilaian kemampuan dan kepatutan.

b. melakukan pengaturan dan pengawasan terhadap BHC dan terhadap Fungsi Holding sebagai bagian yang tidak terpisahkan dari tugas pengaturan dan pengawasan Bank.

c. dapat melakukan pemeriksaan terhadap BHC dan Fungsi Holding baik secara berkala maupun sewaktu-waktu dalam hal diperlukan.

Berdasarkan POJK Nomor 39/POJK.03/2017, diatur beberapa hal yang harus dilakukan oleh Pemegang Saham Pengendali (PSP) dalam mengonsolidasikan dan mengendalikan secara langsung seluruh aktivitas Bank yang menjadi anak perusahaannya. Berikut merupakan hal-hal yang diatur dalam POJK Tentang Kepemilikan Tunggal Pada Perbankan Indonesia, antara lain dalam Pasal 2 POJK Nomor 39/POJK.03/2017 disebutkan bahwa Setiap pihak hanya dapat menjadi PSP pada 1 (satu) Bank. Adapun terdapat pengecualian atas hal yaitu bagi:

a. PSP pada 2 (dua) Bank yang masingmasing melakukan kegiatan usaha dengan prinsip berbeda, yakni secara konvensional dan berdasarkan prinsip syariah; dan

b. PSP pada 2 (dua) Bank yang salah satunya merupakan bank campuran (joint venture bank).

Dalam hal pihak yang menjadi PSP melakukan pembelian saham Bank lain sehingga menjadi PSP pada lebih dari 1 (satu) Bank, dan karena setiap pihak hanya dapat menjadi PSP pada 1 (satu) bank, maka pihak yang bersangkutan wajib memenuhi ketentuan sebagaimana dimaksud dalam Pasal 2 ayat (1), yang dilakukan dengan cara sebagaimana diatur dalam Pasal 3, antara lain:
a. melakukan penggabungan atau peleburan atas Bank yang dikendalikan;
b. membentuk BHC

c. membentuk Fungsi Holding.

Pemenuhan ketentuan untuk melakukan penggabungan atau peleburan serta membentuk BHC wajib dilakukan dalam waktu paling lama 1 (satu) tahun setelah pelaksanaan pembelian saham Bank lain yang mengakibatkan yang bersangkutan memenuhi kriteria sebagai PSP dari Bank yang dibeli sebagaimana dimaksud pada ayat (1).

Dalam Pasal 3 ayat (4), pemenuhan ketentuan untuk membentuk fungsi Holding wajib dilakukan dalam waktu paling lama 6 (enam) bulan setelah pelaksanaan pembelian saham Bank lain yang mengakibatkan yang bersangkutan memenuhi kriteria sebagai PSP pada lebih dari 1 (satu) bank.

Berdasarkan permintaan PSP dan Bank yang dikendalikan, Otoritas Jasa Keuangan dapat memberikan perpanjangan jangka waktu penyesuaian pemenuhan ketentuan sebagaimana dimaksud dalam Pasal 2 ayat (1), dalam hal menurut penilaian Otoritas Jasa Keuangan permasalahan yang dihadapi PSP dan/atau Bank yang dikendalikan cukup kompleks sehingga menyebabkan pemenuhan ketentuan sebagaimana dimaksud dalam Pasal 2 ayat (1) tidak dapat diselesaikan dalam jangka waktu sebagaimana dimaksud pada Pasal 3 ayat (3) dan ayat (4).

Dalam hal PSP yang tidak melakukan pemenuhan ketentuan sebagaimana telah disebut di atas, Pasal 11 ayat (1) telah mengatur bahwa PSP dilarang melakukan pengendalian dan dilarang memiliki saham dengan hak suara pada masing-masing Bank lebih dari 10\% (sepuluh persen) dari jumlah saham Bank.

Mekanisme atau Tata Cara Pembentukan BHC dan Pembentukan Fungsi Holding diatur dalam Pasal 5, yang memuat ketentuan bahwa bentuk badan hukum BHC yaitu perseroan terbatas yang didirikan di Indonesia dan sesuai dengan ketentuan peraturan perundangundangan di Indonesia.

Berdasarkan ketentuan Pasal 5 ayat (2) BHC hanya dapat melakukan kegiatan penyertaan, mencakup penyediaan jasa manajemen untuk meningkatkan efektivitas konsolidasi, strategi usaha, dan optimalisasi keuangan kelompok usaha yang dikendalikan. 
BHC berada 1 (satu) tingkat di atas Bank yang dikendalikan secara langsung. BHC dapat berdiri sendiri sebagai 1 (satu) badan hukum atau berupa perusahaan induk di bidang keuangan (financial holding company) yang mengonsolidasikan lembaga keuangan yang dimiliki oleh PSP.

Berdasarkan Pasal 6, Fungsi Holding hanya dapat dilakukan PSP berupa Bank yang berbadan hukum Indonesia atau instansi Pemerintah Pusat. Fungsi Holding dipimpin oleh salah satu anggota direksi pada Bank yang menjadi PSP atau salah satu pejabat yang ditunjuk oleh pimpinan tertinggi instansi Pemerintah Pusat.

PSP yang memilih untuk membentuk BHC wajib menyampaikan rencana pelaksanaan pembentukan BHC dan pengalihan saham dari PSP kepada BHC kepada Otoritas Jasa Keuangan, dengan melampirkan dokumen pendukung paling sedikit:

1) berita acara Rapat Umum Pemegang Saham masing-masing Bank;

2) rancangan anggaran dasar pendirian $\mathrm{BHC}$;

3) rancangan akta pengalihan saham Bank; dan

4) daftar calon anggota direksi dan/atau anggota dewan komisaris BHC.

Proses pengalihan saham dari PSP kepada BHC dikecualikan dari ketentuan peraturan perundang-undangan mengenai penggabungan, peleburan, dan pengambilalihan bank umum, serta ketentuan peraturan perundang-undangan mengenai pembelian saham bank umum.

Pengalihan saham dari PSP kepada BHC yang dilakukan berdasarkan kewajiban dalam ketentuan ini dikecualikan dari ketentuan yang berlaku bagi calon pemegang saham Bank untuk menyesuaikan kepemilikan sahamnya dengan batas maksimum kepemilikan saham sebagaimana dimaksud dalam ketentuan Otoritas Jasa Keuangan yang mengatur mengenai kepemilikan saham bank umum. Bank yang membentuk Fungsi Holding wajib menyampaikan informasi dan dokumen pendukung mengenai pelaksana Fungsi Holding dan rencana pelaksanaannya kepada Otoritas Jasa Keuangan. BHC dan Fungsi
Holding wajib memberikan arah strategis dan mengonsolidasikan laporan keuangan Bank yang menjadi anak perusahaan.

PSP yang tidak melakukan pemenuhan ketentuan sebagaimana dimaksud dalam Pasal 2 ayat (1) wajib mengalihkan kelebihan saham di atas $10 \%$ (sepuluh persen) sebagaimana dimaksud dalam Pasal 11 ayat (3) kepada pihak lain paling lama 1 (satu) tahun setelah berakhirnya jangka waktu pemenuhan ketentuan sebagaimana dimaksud dalam Pasal 3 ayat (3) dan Pasal 3 ayat (4).

Bank yang akan diambil alih oleh pihak yang telah menjadi PSP sebagaimana dimaksud dalam Pasal 2 ayat (1) wajib menyampaikan rencana pemenuhan ketentuan tersebut kepada Otoritas Jasa Keuangan pada saat mengajukan izin pengambilalihan, yang memuat paling sedikit cara yang dipilih, rencana tindak (action plan), dan jadwal waktu pelaksanaan.

Rencana pemenuhan ketentuan tersebut dapat disusun dan disampaikan oleh masingmasing Bank atau bersama-sama oleh beberapa Bank dengan PSP yang sama dan wajib ditandatangani oleh direksi dan dewan komisaris masing-masing Bank serta diketahui oleh PSP.

Bank yang akan diambil alih oleh pihak yang telah menjadi PSP wajib menyampaikan laporan perkembangan pelaksanaan pemenuhan ketentuan kepada Otoritas Jasa Keuangan setiap triwulan terhitung sejak persetujuan Bank atas rencana pemenuhan ketentuan sebagaimana dimaksud dalam Pasal 2 ayat (1) POJK.

Rencana pemenuhan ketentuan serta laporan perkembangan pelaksanaan pemenuhan ketentuan disampaikan kepada:

a. Departemen Pengawasan Bank terkait atau

Departemen Perbankan Syariah bagi Bank yang berkantor pusat di wilayah Provinsi Daerah Khusus Ibukota Jakarta; atau

b. Kantor Regional Otoritas Jasa Keuangan atau Kantor Otoritas Jasa Keuangan setempat, sesuai dengan wilayah tempat kedudukan kantor pusat Bank.

Dalam hal Bank dan PSP tidak melakukan pemenuhan ketentuan yang dimaksud pada Pasal 2 ayat (1), maka 
berdasarkan ketentuan Pasal 11, bank dengan PSP wajib mencatat kepemilikan saham dan hak suara dalam Rapat Umum Pemegang Saham paling tinggi sebesar 10\% (sepuluh persen) dari jumlah saham Bank. Di samping itu, bank juga wajib menatausahakan jumlah kelebihan saham di atas $10 \%$ (sepuluh persen) milik PSP sebagai saham tanpa hak suara sampai dengan saham dimaksud dialihkan kepada pihak lain.

Pelanggaran terhadap ketentuan sebagaimana dimaksud dalam Pasal 3 ayat (3), Pasal 3 ayat (4), Pasal 7 ayat (1), Pasal 8 ayat (2), Pasal 9 ayat (1), Pasal 10 ayat (1), Pasal 10 ayat (3), dan/atau Pasal 10 ayat (4) Peraturan Otoritas Jasa Keuangan tentang Kepemilikan Tunggal pada Perbankan di Indonesia, dikenakan sanksi administratif berupa:

a. teguran tertulis; dan/atau

b. pencantuman anggota direksi, anggota dewan komisaris, dan/atau pejabat eksekutif dalam daftar pihak yang mendapat predikat Tidak Lulus dalam uji kemampuan dan kepatutan sebagaimana diatur dalam ketentuan peraturan perundang-undangan mengenai uji kemampuan dan kepatutan (fit and proper test).

Bank yang tidak melaksanakan kewajiban pencatatan kepemilikan saham dan hak suara dalam Rapat Umum Pemegang Saham paling tinggi sebesar $10 \%$ dari jumlah saham bank dan menatausahakan jumlah kelebihan saham di atas $10 \%$ milik PSP sebagai saham tanpa hak suara sampai dengan saham dimaksud dialihkan kepada pihak lain, sebagaimana dimaksud dalam Pasal 11 ayat (2) dan/atau Pasal 11 ayat (3), dikenakan:

a. sanksi administratif berupa denda sebesar Rp500.000.000,00 (lima ratus juta rupiah); dan/atau

b. sanksi dalam penilaian aspek tata kelola pada penilaian tingkat kesehatan Bank.

PSP yang memiliki lebih dari 1 (satu) Bank namun tidak memenuhi ketentuan sebagaimana dimaksud dalam Pasal 12 dikenakan sanksi administratif berupa larangan menjadi PSP pada seluruh bank di Indonesia untuk jangka waktu 20 (dua puluh) tahun. Pengenaan sanksi ini tidak menghilangkan kewajiban PSP untuk mengalihkan kelebihan saham di atas $10 \%$ (sepuluh persen) sebagaimana dimaksud dalam Pasal 12.

Anggota direksi dan/atau anggota dewan komisaris BHC yang melanggar ketentuan sebagaimana dimaksud dalam Pasal 5 ayat (2) dikenakan sanksi administratif berupa pencantuman anggota direksi dan/atau anggota dewan komisaris BHC dalam daftar pihak yang mendapat predikat Tidak Lulus dalam uji kemampuan dan kepatutan sebagaimana diatur dalam ketentuan peraturan perundangundangan mengenai uji kemampuan dan kepatutan (fit and proper test).

3) Kebijakan Kepemilikan Tunggal Pada Perbankan di Indonesia (Single Presence Policy) Ditinjau dari Teori Kepentingan Dalam Regulasi di Bidang Ekonomi

Peraturan Otoritas Jasa Keuangan Nomor 39/POJK.03/2017 tentang Kepemilikan Tunggal Pada Perbankan Indonesia apabila ditinjau dari teori kepentingan dalam regulasi (hukum) di bidang ekonomi yang dikemukakan oleh Barry $\mathbf{M}$. Mitnick sebagaimana tertuang dalam bukunya yaitu The Political Economy of Regulation, yang terdiri dari empat teori, yaitu:

a. Consumer protection theory (teori perlindungan konsumen)

Peraturan Otoritas Jasa Keuangan Nomor 39/POJK.03/2017 tentang Kepemilikan Tunggal Pada Perbankan Indonesia, sejatinya memiliki semangat positif yang bertujuan untuk melindungi konsumen dari suatu produk dalam hal ini bank sebagai penyedia jasa perbankan bagi nasabah. Single Presence Policy memberi kesempatan bagi bank untuk menjadi entitas dengan struktur perbankan yang sehat dan kuat sehingga dapat melindungi kepentingan masyarakat khususnya nasabah.

b. Industry protection theory (teori perlindungan kepentingan industri atau pelaku usaha)

Peraturan Otoritas Jasa Keuangan Nomor 39/POJK.03/2017 dibentuk dengan tujuan untuk melindungi kepentingan 
kegiatan industri perbankan untuk menjadi entitas dengan struktur perbankan yang sehat dan kuat sehingga mendapat kepercayaan dan reputasi yang baik di mata masyarakat khususnya nasabah.

c. Bureaucratic behavior theory (teori kepentingan birokrasi atau pemerintah)

Otoritas Jasa Keuangan yang merupakan representasi pemerintah dalam menerbitkan POJK Nomor 39/POJK.03/2017, dapat dilihat sebagai upaya pelayanan yang terbaik dari birokrasi yaitu dengan memperluas wewenang dan mandat dalam pelayanan. Dalam hal ini Otoritas Jasa Keuangan selaku regulator berupaya memberikan pelayanan terbaik bagi masyarakat khususnya nasabah bank dengan membentuk iklim perbankan yang dapat melindungi kepentingan nasabah, dan bagi dunia perbankan dalam rangka mewujudkan struktur perbankan yang sehat. Selain itu bagi PSP dan Bank dalam melayani pemenuhan kewajiban PSP dan Bank yang diamanahkan dalam POJK tersebut.

d. Public Interest Theory (Teori Kepentingan Publik)

Peraturan Otoritas Jasa Keuangan Nomor 39/POJK.03/2017 dibuat untuk menjaga keseimbangan dan kepentingan masyarakat secara keseluruhan termasuk guna mewujudkan tujuan nasional pada bidang perbankan dan kepentingan masyarakat selaku nasabah atau konsumen yang menggunakan jasa perbankan.

\section{KESIMPULAN}

Berdasarkan pembahasan pada bab sebelumnya, maka dapat ditarik kesimpulan dalam penulisan ini, yakni sebagai berikut:

1. Kebijakan kepemilikan tunggal (single presence policy) pada perbankan di Indonesia adalah salah satu cara yang digunakan dalam mewujudkan konsolidasi perbankan yang merupakan salah satu prasyarat untuk mewujudkan struktur perbankan Indonesia yang sehat dan kuat. Fungsi regulasi dalam Single Presence Policy di Indonesia telah beralih dari yang semula oleh Bank Indonesia menjadi fungsi yang dimiliki oleh Otoritas Jasa Keuangan, sejalan dengan terbitnya Peraturan Otoritas Jasa Keuangan Nomor 39/POJK.03/2017 tentang Kepemilikan Tunggal Pada Perbankan Indonesia yang mencabut berlakunya Peraturan Bank Indonesia Nomor 14/24/PBI/2012 tentang Kepemilikan Tunggal pada Perbankan Indonesia, dimana dalam POJK tersebut mengatur ketentuan dan mekanisme yang perlu ditempuh oleh PSP dan Bank dalam pembentukan Bank Holding Company (BHC) dan Pelaksanaan Fungsi Holding.

2. Peraturan Otoritas Jasa Keuangan Nomor 39/POJK.03/2017 tentang Kepemilikan Tunggal Pada Perbankan Indonesia relevan dengan teori kepentingan dalam regulasi (hukum) di bidang ekonomi yang dikemukakan oleh Barry M. Mitnick antara lain Consumer protection theory (teori perlindungan konsumen), Industri protection theory (teori perlindungan kepentingan industri atau pelaku usaha), Bureaucratic behavior theory (teori kepentingan birokrasi atau pemerintah), dan Public Interest Theory (Teori Kepentingan Publik).

\section{SARAN}

Peraturan Otoritas Jasa Keuangan Nomor 39/POJK.03/2017 tentang Kepemilikan Tunggal Pada Perbankan Indonesi masih perlu dilakukan evaluasi secara berkala sesuai kebutuhan dan perkembangan zaman, khususnya terkait ketentuan dimana Otoritas Jasa Keuangan dapat memberikan perpanjangan jangka waktu penyesuaian pemenuhan ketentuan sebagaimana dimaksud dalam Pasal 2 ayat (1), dalam hal menurut penilaian Otoritas Jasa Keuangan permasalahan yang dihadapi PSP dan/atau Bank yang dikendalikan cukup kompleks sehingga menyebabkan pemenuhan ketentuan sebagaimana dimaksud dalam Pasal 2 ayat (1) tidak dapat diselesaikan dalam jangka waktu yang telah ditentukan.

Otoritas Jasa Keuangan perlu mengkaji dan mengklasifikasikan hal-hal apa saja yang tergolong kompleks, sehingga pelaksanaan administrasi dalam pemenuhan ketentuan 
dalam pembentukan BHC dalam rangka pelaksanaan Kepemilikan Tunggal Pada Perbankan di Indonesia dapat berjalan secara efektif dan efisien. Tentunya dari sisi bank yang akan melakukan pembentukan BHC juga harus sebisa mungkin dengan upaya terbaiknya memenuhi ketentuan POJK Nomor: 39/POJK.03/2017 dengan penuh tanggungjawab.

\section{DAFTAR PUSTAKA}

\section{Buku/Literatur}

Bruggink, J.J.H.. 1999. Refleksi Tentang Hukum, Terjemahan Bernard Arief Sidharta, Bandung: Citra Aditya Bhakti.

Djumhana, Muhammad. 1993. Hukum Perbankan di Indonesia, Bandung: Alumni.

Fuady, Munir. 1999. Hukum Perbankan Modern Buku Kesatu, Bandung: Citra Aditya Bakti.

Gazali, Djoni S., Rachmadi Usman. 2012. Hukum Perbankan, Jakarta : Sinar Grafika.

Juwana, Hikmahanto, Bunga Rampai Hukum Ekonomi dan Hukum Internasional. 2002. Jakarta: Lentera.

Lash, Nicholas A. 1987. Banking Laws and Regulations: An Economic Perspective, USA: Prentice Hall Inc.

Marzuki, Peter Mahmud. 2013. Penelitian Hukum, Edisi Revisi, Jakarta: Kencana.

Sembiring, Sentosa. 1993. "Sinopsis Hukum Perbankan", dalam Percikan Gagasan Tentang Hukum II: Kumpulan Tulisan Ilmiah Hukum Alumni dan Dosen Fakultas Hukum UNPAR, A.F. Erawaty et.al., Bandung: Citra Aditya Bakti.

\section{Artikel atau Jurnal}

Elyasiani, Elyas, and Yong Wang. 2012. "Bank holding company diversification and production efficiency", Applied Financial Economics ISSN 0960-3107 print/ISSN 1466-4305 online, (Routledge Taylor \& Francis Group.
Lubis, Todung Mulya. 1990. "In Search of Human Rights; Legal-Political Dilemmas of Indonesia's New Order, 1966-1990", S.J.D. Dissertation at Boalt Hall Law School University of Berkeley.

Surya Iman Wahyudi, "Pendekatan Ekonomi Kearah Penafsiran Konstitusi", Artikel dalam Jurnal Tata Negara Volume 1 Nomor 1. (Jakarta: Pusat Studi Hukum Tata Negara Fakultas Hukum Universitas Indonesia.

Tutik, Titik Triwulan. 2013. "Ilmu Hukum: Hakekat Keilmuannya Ditinjau dari Sudut Filsafat Ilmu dan Teori Ilmu Hukum", Jurnal Hukum dan Pembangunan Tahun ke-43 No.2 April-Juni 2013.

Zaharah, Iftitah. 2014. "Pengawasan Terintegrasi Antara Induk dan Anak Perusahaan Di Bidang Perbankan dan Jasa Keuangan (Suatu Tinjauan Terkait Dengan Konglomerasi di Bidang Keuangan)", Tesis, Program Magister Ilmu Hukum Universitas Indonesia.

Peraturan Perundang-undangan dan Ketentuan Lain

Republik Indonesia, Undang-Undang tentang Perbankan, Undang- Undang No 7 Tahun 1992 sebagaimana telah diubah dengan UU No 10 Tahun 1998, LN Nomor 31 Tahun 1992, TLN Nomor 2865.

Republik Indonesia, Undang-Undang tentang Bank Indonesia, Undang- Undang No 23 Tahun 1999, LN Nomor 66 Tahun 1999, TLN Nomor 3843.

Republik Indonesia, Undang-Undang tentang Perseroan Terbatas, UndangUndang No 40 Tahun 2007, LN Nomor 106 Tahun 2007, TLN Nomor 4756.

Republik Indonesia, Undang-Undang tentang Otoritas Jasa Keuangan, UndangUndang No 21 Tahun 2011, LN Nomor 111 Tahun 2011, TLN Nomor 5253.

Otoritas Jasa Keuangan, Peraturan Otoritas Jasa Keuangan tentang Kepemilikan 
Tunggal Pada Perbankan Indonesia, POJK Nomor 39/POJK.03/2017. 